\title{
Does Emotional Intelligence Prevent Workplace Bullying? A Research on Sports Institution Employees
}

\author{
Tuncay Öcal (Corresponding author) \\ Faculty of Sport Sciences, Aksaray University, Aksaray, Turkey \\ Tel: 90-505-524-5553_E-mail: tuncayocal@aksaray.edu.tr \\ İbrahim Şahin \\ Faculty of Sport Sciences, Yalova University, Yalova, Turkey \\ Tel: 90-543-281-1228Ｅ-mail: ibrahim.sahin@yalova.edu.tr
}

Nuriye Şeyma Kara

School of Physical Education and Sports, Hatay Mustafa Kemal University, Hatay, Turkey

Tel: 90-530-901-2543Ｅ-mail: nuriyeseymasar@mku.edu.tr

Merve Nur Yaşar

Faculty of Sport Sciences, Sakarya University of Applied Sciences, Sakarya, Turkey

Tel: 90-530-300-1931_E-mail: merveyasar@subu.edu.tr

Serkan Necati Metin

Faculty of Sport Sciences, Bandırma Onyedi Eylül University, Bandırma/Balıkesir, Turkey

Tel: 90-544-559-3936_E-mail: serkannecatimetin@gmail.com

Received: November 22, 2021

Accepted: December 22, 2021

Published: December 31, 2021

doi:10.5296/jei.v7i2.19225 URL: https://doi.org/10.5296/jei.v7i2.19225 


\section{Abstract}

This study aimed to investigate the relationship between emotional intelligence and workplace bullying in the Provincial Directorate of Youth Services and Sports. 309 (215 men, 94 women) Sports Provincial Directorate of Youth Services staff from seven different cities of Turkey participated as volunteers in the research. In the study, the personal information form prepared by the researcher, the "Wong and Law Emotional Intelligence Scale" developed by Wong and Law (2002) and adapted to Turkish by Deniz (2012) were used. To determine the workplace bullying level, 21-question "Negative Behaviors Scale" developed by Einarsen (1996) and adapted to Turkish by Cemaloglu (2007) was used. A statistically significant difference was found between the groups according to the emotional intelligence level in the sub-dimension of evaluation of others' emotions in terms of gender variables. No statistically significant difference was determined between the groups according to the gender variable in terms of workplace bullying. A statistically significant difference was found between the groups in terms of the duration of work, according to emotional intelligence levels and workplace bullying. When the relationship between emotional intelligence and workplace bullying was examined, it was found that there were negative significant correlations in some sub-dimensions. As the level of emotional intelligence of the employees increased, the cases of exposure to bullying decreased.

Keywords: Emotional intelligence, Workplace bullying, Sport institution

\section{Introduction}

For individuals who spend most of their time in the workplace, the relationships with employees and management in the work environment have an important place in terms of the efficiency and health of the individual. In this context, behavioral scientists are united in the view that being healthy and productive in personal or organizational life is possible by having good relations with others (Doubtfire, 1997). However, in the ever-changing world, humans also being renewable have created various problems (Çınar \& Özyürek, 2015). One of the most important problems in recent years is workplace bullying. Workplace bullying is defined as harassment, insult, social exclusion, or a situation that has a negative effect on an employee's performance in the workplace (Glasø \& Notelaers, 2012). It is stated that the basic facts in the definition of bullying are the negative and undesirable nature of the behavior of bullying. Although the negative and undesirable nature of the behavior is essential for the concept of bullying, the important feature of the bullying behavior is not only the type of behaviors itself, but the pattern and permanence of these experiences (Einarsen \& Hoel, 2008). From here, the subtler behaviors such as bullying at work, verbal abuse or harm threat within the organization, persistent criticism, humiliating words, intimidation, and punishment can be found, and also refusing to cooperate, not helping, preventing help, blocking someone's performance and making their work difficult are also emphasized (Y. Çelik \& S. Ş. Çelik, 2007; Guidroz et al., 2010; Hutchinson et al., 2010). It is stated that such bullying weakens the work performance by wearing down the people who are exposed to this behavior both physically and psychologically (Balducci, Alfano, \& Fraccaroli, 2009; Glasø et al., 2009; Hogh, Mikkelsen, \& Hansen, 2011; Rodríguez-Muñoz et al., 2009). Hutchinson et 
al. (2013) state that bullying may be considered as emotional abuse Lovell and Lee (2011), suggest that concerns about reducing negative reactions from bullying can be investigated from emotional perspectives. When it comes to work-life, employees communicate and interact with many people, and emotions, goals, attitudes, and intentions show many verbal and non-verbal signs that provide important information about employee performance and group dynamics (Rafaeli \& Sutton, 1987; Sutton, 1991; Cote \& Miners, 2006).

People with high emotional intelligence can use this information for high task performance, it is also emphasized that they can change the organizational climate by perceiving others' emotional states correctly, demonstrating the ability of colleagues to provide interpersonal communication and increase performance (Law, Wong, \& Song, 2004). It has also been reported in the literature that the person exposed to bullying at work can trigger positive or negative emotions depending on how he or she evaluates this situation (Brotheridge \& Lee, 2010). Based on these approaches, Muchinsky (2000) states that emotions have an important place to understand the reactions of people in the workplace. Although there are many studies and models in the field of emotional intelligence (Cherniss et al., 2006), Mayer et al. (1997), who have an important place in this area, have four basic skills that define emotional intelligence; to perceive the emotions of oneself and others correctly, the ability to use emotions to facilitate thinking, the ability to understand emotions, emotional language and the signals that emotions convey and the ability to manage emotions to achieve specific goals (Mayer, Salovey, \& Caruso, 2004; Soylu, Ayan, \& Salman, 2017), stated that employees who have high emotional intelligence can be more successful in managing their emotions, analyzing emotional problems and managing stress, and have more constructive and positive reactions in social relations in addition to the ability to increase work performance by motivating themselves. The area in which managers and people working in the field of human resources expect to bring to the optimal level is known as work performance. Emotional intelligence is therefore defined as an effective ability for organizational success. At the same time, coping with bullying also indicates that the emotional intelligence skills that managers often use can reduce the negative impact of bullying on job performance against the workplace bullying that employees may be exposed to Ashraf and Khan (2014). In previous studies, it was reported that managers were inclined to behave harsh and rude, that workers could not react appropriately to the bullying behavior they were exposed to because they could not fully read their feelings Sheehan and Jordon (2000) and they were directed towards bullying behavior as a result of low emotional intelligence. For the people exposed to bullying, considering that people with high emotional intelligence use life skills more effectively and balanced, it is stated that the negative psychological effects that occur as a result of bullying (Fineman, 2004; Giorgi, 2010) can be solved by using the psychologically adaptable ability of emotionally intelligent people, when they are considered to be proficient in emotional management (Fernandez-Berrocal et al., 2006).

Considering the relationship between psychological violence and emotional intelligence, the aim of this study is to examine the relationship between the levels of bullying and emotional intelligence of individuals working in the Provincial Directorate of Youth Services and Sports. 


\section{Method}

In this study, the relational screening model was used to examine the relationship between the emotional intelligence and workplace bullying of the personnel working in the Provincial Directorate of Youth Services and Sports. The relational survey model is a research model that aims to determine the presence and/or degree of coexistence between two or more variables (Karasar, 2013).

\subsection{Participants}

In this study, the deliberate (judicial) sampling method Sekaran (1992) from non-random sampling methods Black (2009) was used. In this method, the people who form the sample group are composed of the people who the researcher believes will answer the research problem. The criterion in determining the sample group is considered to be the judgment of the researcher. The sample of the study consisted of 94 women and 215 men working in Provincial Directorate of Youth Services and Sports in 12 different cities. When the sample group is examined by title status, it consists of workers (Hogh, Mikkelsen \& Hansen, 2011), civil servants (138) and coaches (123). When examined according to the work year variable, it is seen that there are 95 people with working year in the range of 1-5 years and 214 people with working year 6 and more.

\subsection{Procedures}

This research was carried out using the "Wong and Law Emotional Intelligence Scale" and the "Negative Acts Scale"

\subsubsection{Wong and Law Emotional Intelligence Scale}

Emotional intelligence scale was developed by Wong and Law (2002) and Turkish adaptation was done by Deniz (2011). Law, Wong, and Song (2004) conducted the validity study of the scale in the field of management. The scale consisted of four dimensions and, included in the original scale of the scale, 1 to 4 items were to be able to assess their own feelings, 5 to 8 items were to assess the feelings of others, 9 to 12 items were to utilization of emotions, 13 to 16 items were the size of emotion control. The Cronbach Alpha coefficient was .91 for 'to assess one's own emotions' sub-dimension, the Cronbach Alpha coefficient was .85 for to assess others' emotions' sub-dimension, the Cronbach Alpha coefficient was .82 for 'to utilize one's emotions' sub-dimension, and the Cronbach Alpha coefficient was .91 for 'the control of emotions' sub-dimension.

\subsubsection{Negative Acts Scale}

The Turkish Version of the Negative Acts Questionnaire (NAQ), developed by Einarsen and Raknes (1997), was conducted by Cemaloglu (2007). The scale is used as one-dimensional. In this study, the Cronbach Alpha coefficient of the scale was .94.

\subsection{Statistical Analysis}

Data were collected by face-to-face interview method and paper-and-pencil test. It took approximately 25 minutes to fill the scales. SPSS v. 21 statistics program was used to analyze 
the data. For the analysis of the data, it was checked whether the variances were distributed homogeneously for the selection of the appropriate tests. When the Skewness and Kurtosis values were examined, it was determined that the variances ranged between -1.5 and +1.5 and the variances were homogeneous. According to this, independent samples T-Test was used to test the difference between the two groups and Pearson product-moment correlation test was used to examine the relationship between emotional intelligence and workplace bullying.

\section{Results}

In this part of the research, data were interpreted by creating tables to measure the relation between the emotional intelligence and workplace bullying of the personnel working in the Provincial Directorates of Youth Services and Sports and to explain the relationship for different variables.

Table 1. T-Test results of Emotional Intelligence and Negative Acts Scale in terms of the gender variables of employees

\begin{tabular}{|c|c|c|c|c|c|c|}
\hline & $\mathrm{N}$ (Female/Male) & $\mathrm{X}$ & $\mathrm{SD}$ & $\mathrm{df}$ & $\mathrm{t}$ & $\mathrm{p}$ \\
\hline \multirow{2}{*}{ Self- Emotions Appraisal } & 94 & 4.16 & .84 & \multirow{2}{*}{307} & \multirow{2}{*}{1.207} & \multirow{2}{*}{0.22} \\
\hline & 215 & 4.03 & .91 & & & \\
\hline \multirow{2}{*}{ Others- Emotions Appraisal } & 94 & 4.11 & .64 & \multirow{2}{*}{307} & \multirow{2}{*}{2.499} & \multirow{2}{*}{$0.01 *$} \\
\hline & 215 & 3.86 & .86 & & & \\
\hline \multirow{2}{*}{ Use of Emotion } & 94 & 4.01 & .71 & \multirow{2}{*}{307} & \multirow{2}{*}{.977} & \multirow{2}{*}{0.32} \\
\hline & 215 & 3.91 & .86 & & & \\
\hline \multirow{2}{*}{ Regulations of Emotion } & 94 & 3.61 & 1.06 & \multirow{2}{*}{307} & \multirow{2}{*}{-.247} & \multirow{2}{*}{0.80} \\
\hline & 215 & 3.65 & .99 & & & \\
\hline \multirow{2}{*}{ WLEIS } & 94 & 3.97 & .62 & \multirow{2}{*}{307} & \multirow{2}{*}{1.313} & \multirow{2}{*}{0.19} \\
\hline & 215 & 3.86 & .72 & & & \\
\hline \multirow{2}{*}{ Negative Acts } & 94 & 1.81 & .69 & \multirow{2}{*}{307} & \multirow{2}{*}{-.726} & \multirow{2}{*}{0.46} \\
\hline & 215 & 1.87 & .67 & & & \\
\hline
\end{tabular}

Note. ${ }^{*} \mathrm{p}<0.05$ statistically significant.

In Table 1, T-Test results are given according to the gender variable of the employees. According to the gender variable, there is a statistically significant difference between the groups in the sub-dimension of 'to assess others' emotions' $(p<0.05)$. Accordingly, it is determined that women have a higher emotional intelligence level in the sub-dimension of 'to assess others' emotions' than men. There was no statistically significant difference between 
the groups according to the scores of other Emotional Intelligence sub-dimensions and Negative Acts Scale $(\mathrm{p}>0.05)$.

Table 2. T-Test results by Emotional Intelligence and Negative Acts Scale scores of employees according to working time variable

\begin{tabular}{|c|c|c|c|c|c|c|}
\hline & $\mathrm{N}(1-4$ Years $/ 5+)$ & $\mathrm{X}$ & SD & df & $\mathrm{t}$ & $\mathrm{p}$ \\
\hline \multirow{2}{*}{ Self- Emotions Appraisal } & 95 & 4.09 & .82 & \multirow{2}{*}{307} & \multirow{2}{*}{.254} & \multirow{2}{*}{0.79} \\
\hline & 214 & 4.06 & .92 & & & \\
\hline \multirow{2}{*}{ Others- Emotions Appraisal } & 95 & 3.82 & .86 & \multirow{2}{*}{307} & \multirow{2}{*}{-1.691} & \multirow{2}{*}{0.09} \\
\hline & 214 & 3.99 & .78 & & & \\
\hline \multirow{2}{*}{ Use of Emotion } & 95 & 3.76 & .82 & \multirow{2}{*}{307} & \multirow{2}{*}{-2.653} & \multirow{2}{*}{$0.08^{*}$} \\
\hline & 214 & 4.02 & .81 & & & \\
\hline \multirow{2}{*}{ Regulations of Emotion } & 95 & 3.34 & 1.01 & \multirow{2}{*}{307} & \multirow{2}{*}{-3.431} & \multirow{2}{*}{$0.00^{*}$} \\
\hline & 214 & 3.77 & .99 & & & \\
\hline \multirow{2}{*}{ WLEIS } & 95 & 3.75 & .64 & \multirow{2}{*}{307} & \multirow{2}{*}{-2.447} & \multirow{2}{*}{$0.01 *$} \\
\hline & 214 & 3.96 & .70 & & & \\
\hline \multirow{2}{*}{ Negative Acts } & 95 & 1.74 & .62 & \multirow{2}{*}{307} & \multirow{2}{*}{-2.025} & \multirow{2}{*}{$0.04^{*}$} \\
\hline & 214 & 1.91 & .70 & & & \\
\hline
\end{tabular}

Note. ${ }^{*} \mathrm{p}<0.05$ statistically significant.

In Table 2, T-Test results of the employees according to the working time variable are given. There was a statistically significant difference between the groups according to working time variable for 'to utilize one's emotions' and 'the control of emotions' sub-dimensions with the emotional intelligence general average and scores of Negative Acts evaluation scale $(\mathrm{p}<$ 0.05). Accordingly, it is seen that people who have working time at the same workplace for 5 years and more have higher Emotional Intelligence level in 'to utilize one's emotions', 'the control of emotions' sub-dimensions and 'emotional intelligence average' than people with working time of 1-4 years. According to the scores obtained from the Negative Acts evaluation scale, it is determined that people with working experience of 5 years and more are exposed to more bullying and mobbing behaviors than those with less working time. 
Table 3. Correlation table for employee Emotional Intelligence and Negative Acts evaluation scale scores

\begin{tabular}{|l|l|l|l|l|l|}
\hline & $\begin{array}{l}\text { Self-Emotions } \\
\text { Appraisal }\end{array}$ & $\begin{array}{l}\text { Others-Emotions } \\
\text { Appraisal }\end{array}$ & $\begin{array}{l}\text { Use of } \\
\text { Emotion }\end{array}$ & $\begin{array}{l}\text { Regulations of } \\
\text { Emotion }\end{array}$ & WLEIS \\
\hline Negative Acts & $-.237^{* *}$ & $-.151^{* *}$ & -.033 & $-.123^{*}$ & $-.175^{* *}$ \\
\hline
\end{tabular}

Note. $* \mathrm{p}<0.05 ; * * \mathrm{p}<0.01$ statistically significant.

In Table 3, emotional intelligence and negative acts evaluation scale scores correlation test results are given. It is seen that there is a significant negative relation for 'to assess one's emotions', 'to assess others' emotions', 'the control of emotions' and emotional intelligence average. It can be stated that as the emotional intelligence levels of people increase, the level of bullying in the workplace will decrease.

\section{Discussion}

In developed and developing countries, bullying as a threat of workplace hazard and bullying at the workplace has reached alarming levels, and this situation is due to the deterioration of working conditions (Duffy \& Sperry, 2007; Godin, 2004; Waters et al., 2005). Additionally, researchers Lee and Brotheridge (2006); Saunders et al. (2007) describe one of these conditions, bullying, as repeated, unreasonable, inappropriate behaviors that cause psychological, physical distress and harm to employees. According to the results of many studies in this field (Mikkelsen \& Einarsen, 2001; Cooper, Hoel, \& Faragher, 2004; Bowling \& Beehr, 2006; Topa, Depolo, \& Morales, 2007; Gülle \& Soyer, 2017), exposure to bullying in the workplace affects employees' health, welfare, institutional performance and, moreover, in social context, brings serious and negative consequences. Researches in the field of Victimology (Janoff-Bulman, 1992) has shown that harassment in the workplace can be experienced as a trauma and therefore may produce severe emotional reactions such as fear, anxiety and shock, as well as reduce the positive emotions of the target. It was stated that along with the experience of bullying, feelings such as anxiety, fear, anger, helplessness and nervousness may emerge (Ayoko, Callan, \& Hartel, 2003). As a result of organizational change and many other work-related experiences Mossholder et al. (2000), the interest in the role of emotions in the workplace has begun to gain importance Cartwright and Pappas (2008).

When the relationship between emotions, emotional intelligence and gender was examined, it was seen that there were various differences between men and women. Generally, the emotional dimension of life is associated with women more than men (Grossman \& Wood, 1993), and in some views it is expressed in the sense that the woman is more emotional (Grewal \& Salovey, 2005). Researchers Baron-Cohen (2009); Gur et al. (2002), biological areas of the brain in some areas dedicated to emotional processing of women may be larger than men' stated. In this context, in the present study, it was observed that women employees have higher emotional intelligence than men in sub-dimension of 'to assess others' emotions'. 
It is emphasized that women who interact more with the emotional world (Candela Agullo et al., 2002) are more interested in maintaining their relationships with other people in a positive way and building satisfactory social partnerships in order to conduct their relations with other people (Nolen-Hoeksema \& Jackson, 2001). Additionally, it is also stated that different studies have different opinions. In fact, Goleman (1998) suggested that similarities between groups would be greater than differences when examining widescale groups like gender-specific groups. Many researchers supported (Soylu et al., 2016; Ayan et al., 2017; Soylu \& Serin, 2017; Salman, Toros, \& Soylu, 2018).

Different results have been revealed in the literature in order to determine whether there is a difference for bullying in the workplace between men and women. Salin (2005) stated that data on bullying and gender were inadequate and contradictory. Moreover, some studies have shown that men and women are equally exposed to bullying (Leymann, 1996; Vartia, 1996; Einarsen \& Skogstad, 1996; Quine, 1999; Hoel \& Cooper, 2000). This study showed that there was no difference in exposure to bullying according to gender. In the literature, it is observed that there are studies supporting the research result (Einarsen \& Skogstad, 1996; Dündar \& Acar, 2008; Çelik \& Peker, 2010; Ertürk \& Cemaloğlu, 2014).

Mayer, Salovey, and Caruso (2000), who state that emotional intelligence has different characteristics than traditional intelligence, also expresses that emotional intelligence will evolve from childhood to early adulthood. In this study, it was found that there was a statistically significant difference between the groups according to the working time variable for 'to utilize one's emotions' and 'the control of emotions' sub-dimensions and emotional intelligence average and negative acts scale results. According to this, it was determined that people who have working time of 5 years or more have higher emotional intelligence level than those who have working time of 1-4 years in terms of 'to utilize one's emotions, 'the control of emotions' and 'emotional intelligence average'. According to the scores of the negative acts evaluation scale, it is determined that people who have 5 and more years of working experience are exposed to more bullying and mobbing behaviors than those with less working time. In this study, it was found that 57 people with working experience between 1-5 years of age were in the age group of 24-30 and 38 people were aged 31 and over. It has been found that 40 people with working experience of 6 years and more were 24-30 years old and 174 people were 31 years old or more. When the literature is reviewed, recent researches on emotional intelligence extend the adult age range to middle-aged and older adults (Chen, Peng \& Fang, 2016) and these studies consistently show that older adults have significantly higher scores on emotional intelligence than younger adults (Tsaousis \& Kazi, 2013; Gardner \& Qualter, 2011; Chapman \& Hayslip, 2006; Mayer, Salovey, \& Caruso, 2000). It is stated that there is a strong connection between emotional intelligence, age and work experience (Hur, Moon, \& Han, 2014; Hergüner et al., 2018; Liu et al., 2008) stated that employees with high levels of emotional intelligence are more likely to exhibit realistic behaviors than superficial behaviors. For this reason, it is stated that emotional intelligence can be an important prerequisite for the employees who need to manage their emotions in order to exhibit the desirable emotions after getting older in the corporation (Hur, Moon, \& Han, 2014). Karakurt and Silver (2013) stated that the level of emotional abuse was higher in 
young participants, but this situation decreased with the increase in age.

Ashraf and Khan (2014) claim that individuals exposed to bullying in the workplace lack emotional intelligence. Considering the importance of emotions in performance (Wagner \& Ilies, 2008), when a person with a high emotional intelligence is exposed to any form of bullying, it may be necessary for them to control their feelings positively in order not to affect their workplace performance in the short term (Ashraf \& Khan, 2014). When the relationship between emotional intelligence and workplace bullying was examined, it was found that there was a significant negative relation in terms of 'to assess one's emotions', 'to assess others' emotions', 'the control of emotions' sub-dimensions and 'emotional intelligence average'. According to this, it can be said that as people's emotional intelligence levels increase, they will be less exposed to bullying in the workplace and they will be less affected by this bullying. Ashraf and Khan (2014) stated that people who are emotionally intelligent are considering being careful and prudent rather than being inconsiderate and hasty in the face of an event because they are more sensitive to emotions and feelings in interpersonal communication. Emotionally intelligent people, additionally, engage in behaviors that control emotion and increase work performance (Weisinger, 1988).

It is possible to say that people who are masters of emotion control are good in terms of psychological adaptation to negative events (Fernandez-Berrocal et al., 2006) and that they can prevent psychological damage caused by bullying (Fineman, 2004; Giorgi, 2010) with proper emotional management approach (Ashraf \& Khan, 2014) From another point of view, when emotional intelligence plays a moderate role in aggressive behaviors and workplace stress (Slaski \& Cartwright, 2003), it can be said that emotional intelligence plays an effective role in bullying in the workplace in terms of organizational climate, social relations and business performance.

\section{Conclusion}

When the research results are examined, it can be seen that bullying is defined as a serious stress indicator in the workplace (Bowling \& Beehr, 2006; Baillien, De Cuyper, \& De Witte, 2011) and in this context, a number of factors, such as specific personal characteristics and personality structure (Djurkovic, McCormack, \& Casimir, 2006; Glasø et al., 2007) or social support and a good organizational climate (Fairbrother \& Warn, 2003; Muñoz et al., 2006; Giorgi, 2010), seem to play a preventive role between workplace bullying and psychological well-being (Arenas et al., 2015).

As a result, it can be said that emotional intelligence can increase the level of self-awareness of these adverse conditions and to understand the reasons behind the bullying behavior and that this could eliminate negative work, conflict, and low job performance, moreover, it can be said that perhaps more creative ideas can be created and increase the performance of the institution. In addition, the role of educational institutions that provide physical education should be emphasized in increasing this performance. Programs that take into account the emotional intelligence of young people preparing for the business world and raise awareness about bullying in the workplace should be organized in these educational institutions. Since sports institutions are an area where people from different fields of study are working, future 
studies will shed light on whether the managers or employees coming from a culture other than sports culture will make a difference in terms of emotional intelligence and bullying in the workplace.

\section{References}

Arenas, A., Giorgi, G., Montani, F., Mancuso, S., Perez, J. F., Mucci, N., \& Arcangeli G. (2015). Workplace bullying in a sample of italian and spanish employees and its relationship with job satisfaction, and psychological well-being. Frontiers in Psychology, 6, 1912. https://doi.org/10.3389/fpsyg.2015.01912

Ashraf, F., \& Khan, M. A. (2014). Does emotional intelligence moderate the relationship between workplace bullying and job performance? Asian Business \& Management, 13(2), 171-190. https://doi.org/10.1057/abm.2013.5

Ayan, S., Soylu, Y., Bozdal, O., \& Alıncak, F. (2017). Investigation of emotional intelligence level of university students. European Journal of Physical Education and Sport Science, 3(5), 1-11. https://doi.org/10.5281/zenodo.569076

Ayoko, O., Callan, V., \& Hartel, C. (2003). Workplace conflict, bullying, and counterproductive behaviours. International Journal of Organizational Analysis, 11(4), 283-301. https://doi.org/10.1108/eb028976

Baillien, E., De Cuyper, N., \& De Witte, H. (2011). Job autonomy and workload as antecedents of workplace bullying: A two - wave test of Karasek's Job Demand Control Model for targets and perpetrators. Journal of occupational and Organizational Psychology, 84(1), 191-208. https://doi.org/10.1348/096317910X508371

Balducci, C., Alfano, V., \& Fraccaroli, F. (2009). Relationships between mobbing at work and MMPI-2 personality profile, posttraumatic stress symptoms, and suicidal ideation and behavior. Violence and Victims, 24(1), 52. https://doi.org/10.1891/0886-6708.24.1.52

Baron-Cohen, S. (2009). The essential difference: Male and female brains and the truth about autism. Basic Books.

Black, K. (2009). Business statistics: Contemporary decision making. John Wiley \& Sons.

Bowling, N. A., \& Beehr, T. A. (2006). Workplace harassment from the victim's perspective: a theoretical model and meta-analysis. Journal of Applied Psychology, 91(5), 998. https://doi.org/10.1037/0021-9010.91.5.998

Brotheridge, C. M., \& Lee, R. T. (2010). Restless and confused: Emotional responses to workplace bullying in men and women. Career Development International, 15(7), 687-707. https://doi.org/10.1108/13620431011094087

Candela Agulló, C., Barberá Heredia, E., Ramos López, A., \& Sarrió Catalá, M. (2002). Inteligencia emocionaly la variable género. Revista Electrónica de Emocióny Motivación, 5(10), 167-182.

Cartwright, S., \& Pappas, C. (2008). Emotional intelligence, its measurement and 
implications for the workplace. International Journal of Management Reviews, 10(2), 149-171. https://doi.org/10.1111/j.1468-2370.2007.00220.x

Celik, S., \& Peker, S. (2010). Mobbing perceptions of high school teachers. Procedia-Social And Behavioral Sciences, 9, 1617-1623. https://doi.org/10.1016/j.sbspro.2010.12.375

Celik, Y., \& Celik, S. Ş. (2007). Sexual harassment against nurses in Turkey. Journal of Nursing Scholarship, 39(2), 200-206. https://doi.org/10.1111/j.1547-5069.2007.00168.x

Cemaloğlu, N. (2007). Okul yöneticilerinin liderlik stilleri ile yıldırma arasındaki ilişki. Hacettepe Üniversitesi Eğitim Fakültesi Dergisi, 33(33).

Chapman, B. P., \& Hayslip Jr, B. (2006). Emotional intelligence in young and middle adulthood: Cross-sectional analysis of latent structure and means. Psychology and Aging, 21(2), 411. https://doi.org/10.1037/0882-7974.21.2.411

Chen, Y., Peng, Y., \& Fang, P. (2016). Emotional intelligence mediates the relationship between age and subjective well-being. The International Journal of Aging and Human Development, 83(2), 91-107. https://doi.org/10.1177/0091415016648705

Cherniss, C., Extein, M., Goleman, D., \& Weissberg, R. P. (2006). Emotional intelligence: what does the research really indicate? Educational Psychologist, 41(4), 239-245. https://doi.org/10.1207/s15326985ep4104_4

Cınar, M., \& Özyürek, A. (2015). Araştırma görevlisi akademisyenlerin iş yerinde psikolojik şiddet davranışı (mobbing) algısı ve duygusal zekâ düzeyleri arasındaki ilişkinin incelenmesi. Akademik Bakış Uluslararası Hakemli Sosyal Bilimler Dergisi, 47, 141-154.

Cooper, C. L., Hoel, H., \& Faragher, B. (2004). Bullying is detrimental to health, but all bullying behaviours are not necessarily equally damaging. British Journal of Guidance \& Counselling, 32(3), 367-387. https://doi.org/10.1080/03069880410001723594

Cote, S., \& Miners, C. T. (2006). Emotional intelligence, cognitive intelligence, and job performance. Administrative Science Quarterly, 51(1), 1-28. https://doi.org/10.2189/ asqu.51.1.1

Deniz, M. (2011). Duygusal zekâ boyutları ile liderlik uygulamaları arasındaki ilişki: sağlık sektörü yöneticileri üzerine bir araştırma. e-Journal of New World Sciences Academy, 7(2), 45-66.

Djurkovic, N., McCormack, D., \& Casimir, G. (2006). Neuroticism and the psychosomatic model of workplace bullying. Journal of Managerial Psychology, 21(1), 73-88. https://doi.org/10.1108/02683940610643224

Doubtfire, D. (1997). In E. Kayra (Eds.), Insanlarla iyi geçinmenin yolları. İstanbul: Rota Yayınlar1.

Duffy, M., \& Sperry, L. (2007). Workplace mobbing: Individual and family health consequences. The Family Journal, 15(4), 398-404. https://doi.org/10.1177/106648070 7305069 
Dündar, G., \& Acar, A. (2008). İşyerinde psikolojik yıldırmaya(mobbing) maruz kalma sıklığ ile demografik özellikler arasındaki ilişkinin incelenmesi. İstanbul Üniversitesi Isşletme Fakültesi Dergisi, 37(2), 111-120.

Einarsen, S., \& Hoel, H. (2008). Bullying and mistreatment at work: How managers may prevent and manage such problems. Employee well-being support: A workplace resource (pp. 161-173). https://doi.org/10.1002/9780470773246.ch14

Einarsen, S., \& Raknes, B. I. (1997). Harassment in the workplace and the victimization of men. Violence and Victims, 12(3), 247. https://doi.org/10.1891/0886-6708.12.3.247

Einarsen, S., \& Skogstad, A. (1996). Bullying at work: Epidemiological findings in public and private organizations. European Journal of Work and Organizational Psychology, 5(2), 185-201. https://doi.org/10.1080/13594329608414854

Ertürk, A., \& Cemaloğlu, N. (2014). Causes of mobbing behavior. Procedia-Social and Behavioral Sciences, 116, 3669-3678. https://doi.org/10.1016/j.sbspro.2014.01.821

Fairbrother, K., \& Warn, J. (2003). Workplace dimensions, stress and job satisfaction. Journal of Managerial Psychology, 18(1), 8-21. https://doi.org/10.1108/02683940310459565

Fernandez-Berrocal, P., Alcaide, R., Extremera, N., \& Pizarro, D. (2006). The role of emotional intelligence in anxiety and depression among adolescents. Individual Differences Research, 4(1).

Fineman, S. (2004). Getting the measure of emotion-and the cautionary tale of emotional intelligence. Human Relations, 57(6), 719-740. https://doi.org/10.1177/0018726704044953

Gardner, K. J., \& Qualter, P. (2011). Factor structure, measurement invariance and structural invariance of the MSCEIT V2.0. Personality and Individual Differences, 51(4), 492-496. https://doi.org/10.1016/j.paid.2011.05.004

Giorgi, G. (2010). Workplace bullying partially mediates the climate-health relationship. Journal of Managerial Psychology, 25(7), 727-740. https://doi.org/10.1108/026839410110 75274

Glasø, L., \& Notelaers, G. (2012). Workplace bullying, emotions, and outcomes. Violence Victims, 27, 360-377. https://doi.org/10.1891/0886-6708.27.3.360

Glasø, L., Matthiesen, S. B., Nielsen, M. B., \& Einarsen, S. (2007). Do targets of workplace bullying portray a general victim personality profile? Scandinavian Journal of Psychology, 48(4), 313-319. https://doi.org/10.1111/j.1467-9450.2007.00554.x

Glasø, L., Nielsen, M., Einarsen, S., Haugland, K., \& Matthiesen, S. (2009). A study of basic life assumptions and post-traumatic stress disorder among victims of workplace bullying. Journal of the Norwegian Psychological Association, 46: 153-160.

Godin, I. M. (2004). Bullying, worker's health, and labour instability. Journal of Epidemiology and Community Health, 58, 258-259. https://doi.org/10.1136/jech.2003.009456 
Goleman, D. (1998). Duygusal zekâ. İstanbul: Varlık Yayınları.

Grewal, D., \& Salovey, P. (2005). Feeling smart: The science of emotional intelligence: A new idea in psychology has matured and shows promise of explaining how attending to emotions can help us in everyday life. American Scientist, 93(4), 330-339. https://doi.org/ $10.1511 / 2005.54 .969$

Grossman, M., \& Wood, W. (1993). Sex differences in intensity of emotional experience: A social role interpretation. Journal of Personality and Social Psychology, 65(5), 1010. https://doi.org/10.1037/0022-3514.65.5.1010

Guidroz, A. M., Burnfield-Geimer, J. L., Clark, O., Schwetschenau, H. M., \& Jex, S. M. (2010). The nursing incivility scale: Development and validation of an occupation-specific measure. Journal of Nursing Measurement, 18(3), 176. https://doi.org/10.1891/1061-3749. 18.3.176

Gülle, M., \& Soyer, F. (2017). The Relationship between Mobbing and Organizational Commitments of Physical Education and Sport Teachers. International Journal of Educational Sciences, 18(1-3), 73-78. https://doi.org/10.1080/09751122.2017.1351077

Gur, R. C., Gunning-Dixon, F., Bilker, W. B, \& Gur, R. E. (2002). Sex differences in temporo-limbic and frontal brain volumes of healthy adults. Cerebral Cortex, 12(9), 998-1003. https://doi.org/10.1093/cercor/12.9.998

Hergüner, G., Sarıkabak, M., Yaman, N., Soylu, Y., \& Öcal, T. (2018). Investigation of emotional intelligence level of professional football players in Turkish 3th league. Sportif Bakış: Spor ve Eğitim Bilimleri Dergisi, 5(SI1), 46-56.

Hoel, H., \& Cooper, C. L. (2000). Destructive conflict and bullying at work. Manchester: Manchester School of Management, UMIST.

Hogh, A., Mikkelsen, E. G., \& Hansen, A. M. (2011). Individual consequences of workplace bullying/mobbing. Bullying and harassment in the workplace: Developments in Theory, Research, and Practice, 107, 128. https://doi.org/10.1201/EBK1439804896-7

Hur, W. M., Moon, T. W., \& Han, S. J. (2014). The role of chronological age and work experience on emotional labor: The mediating effect of emotional intelligence. Career Development International, 19(7), 734-754. https://doi.org/10.1108/CDI-12-2013-0162

Hutchinson, M., \& Hurley, J. (2013). Exploring leadership capability and emotional intelligence as moderators of workplace bullying. Journal of Nursing Management, 21(3), 553-562. https://doi.org/10.1111/j.1365-2834.2012.01372.x

Hutchinson, M., Wilkes, L., Jackson, D., \& Vickers, M. H. (2010). Integrating individual, work group and organizational factors: Testing a multidimensional model of bullying in the nursing workplace. Journal of Nursing Management, 18(2), 173-181. https://doi.org/10.1111/ j.1365-2834.2009.01035.x

Janoff-Bulman, R. (1992). Shattered assumptions: Towards a new psychology of trauma. 
New York: Free Press.

Karakurt, G., \& Silver, K. E. (2013). Emotional abuse in intimate relationships: The role of gender and age. Violence and Victims, 28(5), 804-821. https://doi.org/10.1891/ 0886-6708.VV-D-12-00041

Karasar, N. (2013). Bilimsel araștırma yöntemi. Ankara: Nobel Yayın Dağıtım.

Law, K. S., Wong, C. S., \& Song, L. J. (2004). The construct and criterion validity of emotional intelligence and its potential utility for management studies. Journal of Applied Psychology, 89(3), 483. https://doi.org/10.1037/0021-9010.89.3.483

Lee, R. T., \& Brotheridge, C. M. (2006). When prey turns predatory: Workplace bullying as a predictor of counteraggression/bullying, coping, and well-being. European Journal of Work and Organizational Psychology, 15(3), 352-377. https://doi.org/10.1080/13594320600636531

Leymann, H. (1996). The content and development of mobbing at work. European Journal of Work and Organizational Psychology, 5(2), 165-184. https://doi.org/10.1080/13594329608 414853

Liu, Y., Prati, L. M., Perrewe, P. L., \& Ferris, G. R. (2008). The relationship between emotional resources and emotional labor: An exploratory study. Journal of Applied Social Psychology, 38(10), 2410-2439. https://doi.org/10.1111/j.1559-1816.2008.00398.x

Lovell, B. L., \& Lee, R. T. (2011). Impact of workplace bullying on emotional and physical well-being: A longitudinal collective case study. Journal of Aggression, Maltreatment \& Trauma, 20(3), 344-357. https://doi.org/10.1080/10926771.2011.554338

Mayer, J. D., Salovey, P., \& Caruso, D. (2000). Models of emotional intelligence. In R. J. Sternberg (Ed.), The handbook of intelligence (pp. 396-420). New York: Cambridge University Perss. https://doi.org/10.1017/CBO9780511807947.019

Mayer, J. D., Salovey, P., \& Caruso, D. R. (2004). Emotional intelligence: Theory, findings and implications. Psychological Inquiry, 15(3), 197-215. https://doi.org/10.1207/s15327965 pli1503_02

Mayer, J. D., Salovey, P., Salovey, P., \& Sluyter, D. (1997). Emotional development and emotional intelligence: Implications for educators. What Is Emotional Intelligence (pp. 3-31).

Mikkelsen, E. G., \& Einarsen, S. (2001). Bullying in Danish work-life: Prevalence and health correlates. European Journal of Work and Organizational Psychology, 10(4), 393-413. https://doi.org/10.1080/13594320143000816

Mossholder, K. W., Settoon, R. P., Armenakis, A. A., \& Harris, S. G. (2000). Emotion during organizational transformations: An interactive model of survivor reactions. Group \& Organization Management, 25(3), 220-243. https://doi.org/10.1177/1059601100253002

Muchinsky, P. M. (2000). Emotions in the workplace: The neglect of organizational behavior. Journal of Organizational Behavior: The International Journal of Industrial, Occupational and Organizational Psychology and Behavior, 21(7), 801-805. https://doi.org/10.1002/ 
1099-1379(200011)21:7\%3C801::AID-JOB999\%3E3.0.CO;2-A

Muñoz, A. R., Gamarra, M. M., Jiménez, B. M., \& Herrer, M. G. (2006). Predictores organizacionales del acoso psicológico en el trabajo: Aplicación del modelo de demandas $\mathrm{y}$ recursos laborales. Revista de Psicología del Trabajo y de las Organizaciones, 22(3), 333-345.

Nolen-Hoeksema, S., \& Jackson, B. (2001). Mediators of the gender difference in rumination. Psychology of Women Quarterly, 25(1), 37-47. https://doi.org/10.1111/1471-6402.00005

Quine, L. (1999). Workplace bullying in NHS community trust: Staff questionnaire survey. Bmj, 318(7178), 228-232. https://doi.org/10.1136/bmj.318.7178.228

Rafaeli, A., \& Sutton, R. I. (1987). Expression of emotion as part of the work role. Academy of Management Review, 12(1), 23-37. https://doi.org/10.2307/257991

Rodríguez-Muñoz, A., Baillien, E., De Witte, H., Moreno-Jiménez, B., \& Pastor, J. C. (2009). Cross-lagged relationships between workplace bullying, job satisfaction and engagement: Two longitudinal studies. Work \& Stress, 23(3), 225-243. https://doi.org/10.1080/0267837 0903227357

Salin, D. (2005). Workplace bullying among business professionals: Prevalence, gender differences and the role of organizational politics. Perspectives Interdisciplinaires Sur Le Travail Et La Santé (pp. 7-3). https://doi.org/10.4000/pistes.3159

Salman, M. N., Toros, T., \& Soylu, Y. (2018). Elit sporcuların duygusal zekâ yönünden karşılaştırılması: Takım ve bireysel sporlar. Electronic Turkish Studies, 13(26). https://doi.org/ 10.7827/TurkishStudies.14442

Saunders, P., Huynh, A., \& Goodman-Delahunty, J. (2007). Defining workplace bullying behaviour professional lay definitions of workplace bullying. International Journal of Law and Psychiatry, 30(4-5), 340-354. https://doi.org/10.1016/j.ijlp.2007.06.007

Sekaran, U. (1992). Instructor's resource guide with test questions and transparency masters to accompany research methods for business: A kill building approach. John Wiley \& Sons.

Sheehan, M., \& Jordan, P. (2000). The antecedents and implications of workplace bullying: A bounded emotionality analysis. Annual Conference of the Association Francophone de Gestion des Ressources Humaines Internationalisation of HRM.

Slaski, M., \& Cartwright, S. (2003). Emotional intelligence training and its implications for stress, health, and performance. Stress and Health, 19(4), 233-239. https://doi.org/10.1002/ smi.979

Soylu, Y., \& Serin, E. (2017). Beden eğitimi ve spor öğretmenlerinin duygusal zekâ düzeylerinin incelenmesi (Aksaray ili örneği). Sportif Bakış: Spor ve Ĕ̆itim Bilimleri Dergisi, 1: $1-9$.

Soylu, Y., Ayan, S., \& Salman, M. N. (2017). 16-21 yaş arası elit düzeydeki takımların genç futbolcularının duygusal zekâ düzeylerinin incelenmesi. Electronic Turkish Studies, 12(17), 
397-410. https://doi.org/10.7827/TurkishStudies.11947

Soylu, Y., Salman, M. N., Y1lmaz, O. Y. O., \& Güzelgöz, G. (2016). The investigation of emotional intelligence of men and women futsal athletes. International Journal of Sport Culture and Science, 4(2), 206-217. https://doi.org/10.14486/IntJSCS514

Sutton, R. I. (1991). Maintaining norms about expressed emotions: The case of bill collectors. Administrative Science Quarterly, 245-268. https://doi.org/10.2307/2393355

Topa, G. C., Depolo, M., \& Morales, J. D. (2007). Mobbing: A meta-analysis and integrative model of its antecedents and consequences.

Tsaousis, I., \& Kazi, S. (2013). Factorial invariance and latent mean differences of scores on trait emotional intelligence across gender and age. Personality and Individual Differences, 54(2), 169-173. https://doi.org/10.1016/j.paid.2012.08.016

Vartia, M. (1996). The sources of bullying-psychological work environment and organizational climate. European Journal of Work and Organizational Psychology, 5(2), 203-214. https://doi.org/10.1080/13594329608414855

Wagner, D. T., \& Ilies, R. (2008). Affective influences on employee satisfaction and performance. Research Companion to Emotion in Organizations (pp. 152-169). https://doi.org/10.4337/9781848443778.00018

Waters, H. R., Hyder, A. A., Rajkotia, Y., Basu, S., \& Butchart, A. (2005). The costs of interpersonal violence: An international review. Health Policy, 73, 303-315. https://doi.org/ 10.1016/j.healthpol.2004.11.022

Weisinger, H. (1988). Emotional intelligence at work. San Francisco, CA: Jossey Bass.

Wong, C. S., \& Law, K. S. (2002). The effects of leader and follower emotional intelligence on performance and attitude: An exploratory study. The Leadership Quarterly, 13(3), 243-274. https://doi.org/10.1016/S1048-9843(02)00099-1

\section{Copyright Disclaimer}

Copyright for this article is retained by the author(s), with first publication rights granted to the journal.

This is an open-access article distributed under the terms and conditions of the Creative Commons Attribution license (http://creativecommons.org/licenses/by/3.0/). 